\title{
A design-based (pre)recruitment approach for new professions: defining futureproof job profiles
}

In a rapidly developing labor market, in which some parts of jobs disappear and new parts appear due to technological developments, companies are struggling with defining future-proof job qualifications and describing job profiles that fit the organization's needs. This is even more applicable to smaller companies with new types of work because they often grow rapidly and cannot hire graduates from existing study programs. In this research project, we undertook in-depth, qualitative research into the five roles of a new profession: social media architect. It has become clear which 21st century skills and motivations are important per role and, above all, how they differ in subcategory and are interpreted by a full-service team in their working methods, in a labor market context, and in the talents of the professional themselves. In a workshop, these "skills" were supplemented through a design-based approach and visualized per team role in flexibly applicable recruitment cards. This research project serves as an example of how to co-create innovative job profiles for the changing labor market.

Keywords: 21st century skills, future-proofjob profiles, design-based recruitment approach

\section{Acknowledgement}

We wish to thank our project partners, an SME of social media architects and a high school; in particular, the interviewees for their openness and ability to explicate the core of their profession. Furthermore, we want to thank our researchers Jeany Slijper, Frans Jacobs and Rachelle van Harn. Finally, we should also thank The Taskforce for Applied Research in the Netherlands (in Dutch: Nationaal Regieorgaan Praktijkgericht Onderzoek SIA) for subsidising this project.

\section{Author Information}

Ellen Sjoer, The Hague University of Applied Sciences, https://www.thehagueuniversity. com/research/research-groups/details/sustainable-talent-development

Petra Biemans, Inholland University of Applied Sciences, https://www.inholland.nl/ onderzoek/onderzoekslijnen/hrm-persoonlijk-ondernemerschap/

\section{How to cite this article:}

Ellen Sjoer, Petra Biemans. "A design-based (pre)recruitment approach for new professions: defining futureproof job profiles.” Információs Társadalom XX, no. 2 (2020): 84-100.

https://dx.doi.org/10.22503/inftars.XX.2020.2.6 


\section{Introduction}

The labor market is changing rapidly. New technology and globalization are the main drivers of economic development. As a result, many new jobs are being created (Miller and Atkinson 2013). Who had ever heard of a drone pilot or ethical hacker before? Technological change, though, is "skills biased". New technologies tend to favor certain skills while devaluing others (Dachs 2018). Specific skills, such as those required for routine tasks have become superfluous (Frey and Osborne 2013, 2017). For many professionals, e.g. in administrative professions, this means a decrease in their employability. On the other hand, a labor shortage is expected for professions with interpersonal, technical, digital, and creative roles (DenkWerk 2019). In these job roles, other qualities are important, these are also referred to as "21st century skills".

As the world keeps developing, there is increasing demand from industry for a workforce with different skills and potential (World Economic Forum 2016). Sustainable employability and lifelong learning feature prominently on HR agendas. Many employers need to reconsider the job profiles of existing staff and of new staff being hired. This is not an easy task. The rate of change is fast and the future is uncertain. The coronavirus shows that the job market can change almost overnight.

It is even more complicated for small enterprises with new types of professions to find the right personnel. These companies are often fast growing, and are looking for an organizational structure that is a natural match with the business process. They often do not have an HR professional or a structured recruitment and selection procedure in place. Our education system does not supply graduates for newly created jobs, making it difficult for companies to find the right staff. For these companies wanting to hire new employees, it is important to gain insight into the novel profiles and the corresponding future job qualifications, often referred to as " 21 st century skills".

As an example, we decided to study one appealing new profession: social media architect (SMA). An SMA helps companies to develop and execute a (media) strategy to achieve impact on a specific target group. It is a crossover between communication and technology. Together with an SMA, we explored a design-based (pre)recruitment approach, which includes additional attention for future-ready 21st century skills. The result could be of interest to all companies that are struggling with new or (radically) changing job positions. If you want to hire a person with future-proof skills and potential, a profound change is needed in the traditional approach to 1) defining future-proof job qualifications (forecasting) and 2) describing the job profile that fits the organization's needs.

The goal of the research is to renew the way companies define job profiles to recruit the most suitable talent for newly created job roles by supporting a small company in the creative sector with a new profession to hire 
the right employees. Moreover, it shows how the 21st century skills can be used in a meaningful way. Finally, this study serves as an example of how universities and SMEs can jointly address the challenges of a changing labor market.

The research questions are as follows:

1. What 21 st century skills does (do) a (team of) social media architect(s) need for which professional activities and professional results?

2. How can these 21 st century skills be visualized per team role so that they can be used in recruitment and selection?

\section{Theoretical framework of the 21st century skills}

The term 21st century skills was introduced to clarify the fact that our future workforce requires different qualities than merely disciplinary knowledge and some soft skills. Several frameworks were created, primarily at schools and universities, to describe the qualities that will become important (Voogt and Roblin 2012). There is a lot of criticism of these "lists" of 21st century skills. The term 21st century skills is considered vague and confusing since there is nothing new about these skills. Moreover, skills such as collaboration and communication are higher-order skills and silo concepts that cannot be developed and measured in a reliable way. Furthermore, research into the debate on the 21st century skills identifies neo-liberal discourses about what constitutes an ideal student (Hilt, Riese and Søreide 2019).

We agree with most of the aforementioned points of criticism. We, too, believe that frameworks of 21 st century skills will not help sufficiently to educate students or to upskill or reskill employees (Biemans et. al. 2017). Moreover, "skills" is probably not the right term. Nevertheless, it is helpful to use a framework to give an idea of the capabilities of our future workforce. We chose to use the "Framework for 21st Century Learning" (P21 model), among other things, because this model is very popular and well documented (Battelle for Kids 2019). The model has been jointly developed in the United States by education, business and government. However, there are some questions about the motives of the P21 Skills Group (Sawchuk 2009). According to some critics, technology companies want to gain more influence over the classroom. The P21 group responded that the opponents do not believe that the education system should be more responsive to business needs.

The P21 framework describes the skills, knowledge, and expertise students must master, represented by a rainbow, to succeed in work and life (see figure 1). It is a blend of content knowledge, specific skills, expertise, and literacies. In this P21 model, the 21st century skills are divided in three clusters, and several components. (see table 1). 


\begin{tabular}{|c|c|c|}
\hline Life and Career Skills & $\begin{array}{c}\text { Learning and } \\
\text { Innovation Skills }\end{array}$ & $\begin{array}{c}\text { Information, Media and } \\
\text { Technology Skills }\end{array}$ \\
\hline Flexibility and adaptability & Creativity & Information literacy \\
\hline Initiative and self-direction & Critical Thinking & Media literacy \\
\hline Productivity and accountability & Collaboration & ICT literacy \\
\hline Leadership and responsibility & Communication & \\
\hline Social and cross cultural skills & & \\
\hline
\end{tabular}

Table 1. Clusters of 21st century student outcomes (P21)

21st Century Student Outcomes and Support Systems

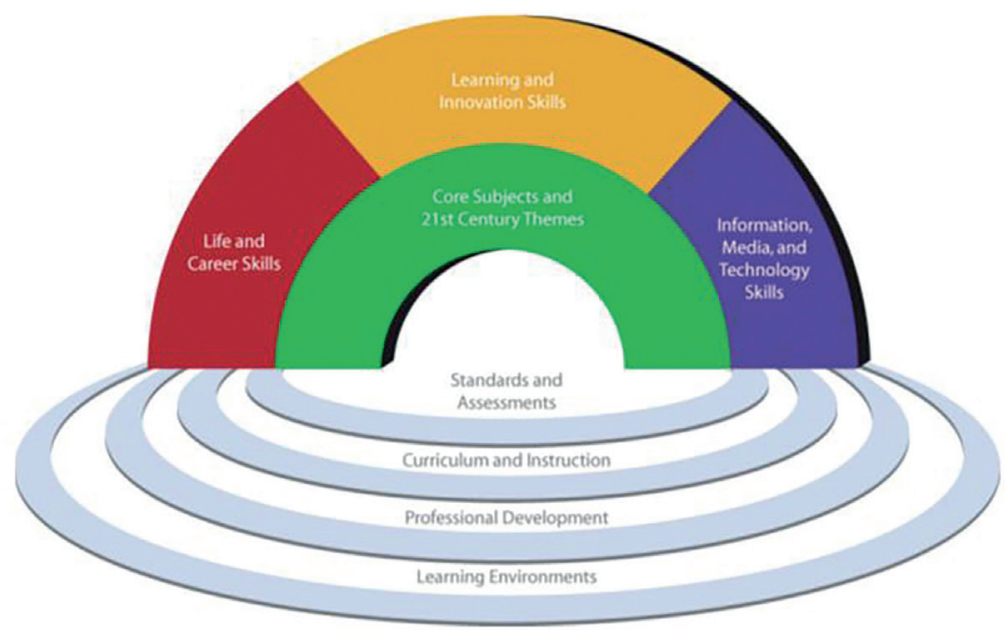

Figure 1. P21 framework of 21st century student outcomes

Besides these skills clusters, proficiency in "core subjects and 21st century themes" is also important for student success. Key subjects include reading, mathematics, history, etc. It is notable that 21st century interdisciplinary themes such as global awareness, entrepreneurial literacy, civic literacy, health and environmental literacy should be intertwined with these key subjects. P21 views all the components of the framework as fully interconnected in the process of 21st century teaching and learning (Battelle for Kids 2019). 


\section{Methodology}

The Taskforce for Applied Research in the Netherlands financed the "Crossovers in Technology-Related Jobs" research project, which consists of six steps (see table 2).

\begin{tabular}{|l|l|}
\hline Step 1 & Preparing the research instruments. \\
\hline Step 2 & $\begin{array}{l}\text { Collecting information about the professional activities and the essential 21st } \\
\text { century skills of a social media architect and the context in which the company } \\
\text { operates. }\end{array}$ \\
\hline Step 3 & $\begin{array}{l}\text { Analyzing the data with a first sketch of a professional image (of a team) of SMAs } \\
\text { as a result. }\end{array}$ \\
\hline Step 4 & $\begin{array}{l}\text { Deepening the concept in a workshop and designing a professional image of the } \\
\text { SMA team together. }\end{array}$ \\
\hline Step 5 & $\begin{array}{l}\text { Validating the different team roles of a social media architect and creating mate- } \\
\text { rial for use in recruitment and selection. }\end{array}$ \\
\hline Step 6 & $\begin{array}{l}\text { Disseminating the results in a knowledge café and starting a discussion on how } \\
\text { to use the material and take it a step further. }\end{array}$ \\
\hline
\end{tabular}

Table 2: Activities per step in the Crossovers in Technology-Related Jobs project.

We executed steps 1-3 to answer research question 1 and steps 4-5 to answer research question 2 . In this chapter we will describe the data collection method and the data analysis in more detail.

\subsection{Respondents and procedure for research question 1}

We conducted a qualitative interview study to describe the professional activities and the associated 21st century skills of an SMA. According to the practitioners, this new profession consists of six roles, which taken together, form the professional profile of an SMA: strategist, designer, copywriter, content manager, videographer and a team head. In the near future, the role of designer and videographer will be combined. This role will be defined by the word: "creative".

Five SMAs were interviewed for approximately 75 minutes each (see table 3). The semi-structured interviews were conducted using an interview template with six blocks of questions. Each interview started with general 
questions about their age, educational background, professional experience. The second block contained questions concerning the area of activity, such as stakeholders, sectors and emerging economic and social trends. This was followed by blocks of questions about the professional activities and the qualifications and competences to meet the objectives of an SMA. The interviewees did not get a list of 21st century skills, but they got questions such as: What is absolutely necessary to do the job well? What would you look for if you want to hire a colleague in your role? Finally, there were questions relating to the motivation for the job and career development. The interviews were recorded and transcribed. All transcripts were then analysed with a software programme, using the six blocks of questions.

\begin{tabular}{|c|c|c|c|}
\hline & Role & Background (study) & $\begin{array}{c}\text { Professional } \\
\text { experience }\end{array}$ \\
\hline 1 & Strategist & $\begin{array}{l}\text { Commercial communication } \\
\text { management (higher vocational } \\
\text { education) }\end{array}$ & $\begin{array}{l}7 \text { years: communication officer/ } \\
\text { manager (at a large tech com- } \\
\text { pany); } 4 \text { months at SMA agency }\end{array}$ \\
\hline 2 & Designer & $\begin{array}{l}\text { Associate degree in graphic } \\
\text { design and art college (UAS) }\end{array}$ & 3.5 years at SMA agency \\
\hline 3 & Copywriter & $\begin{array}{l}\text { Upper vocational secondary } \\
\text { education in business and ad- } \\
\text { ministration }\end{array}$ & $\begin{array}{l}\text { Graphic designer in Screen } \\
\text { printing shop; designer and } \\
\text { copy writer ad agency; (Chief) } \\
\text { editor publishing company; } 6.5 \\
\text { year at SMA agency }\end{array}$ \\
\hline 4 & Content manager & $\begin{array}{l}\text { Communication and Media } \\
\text { (Erasmus University); Master } \\
\text { Corporate Communication } \\
\text { (University of Amsterdam) }\end{array}$ & $\begin{array}{l}\text { Full time in restaurant busi- } \\
\text { ness; online marketer; } 4 \\
\text { months at SMA agency }\end{array}$ \\
\hline 5 & $\begin{array}{l}\text { Videograph/ } \\
\text { teamhead }\end{array}$ & $\begin{array}{l}\text { Economics at university of } \\
\text { applied sciences (minor at art } \\
\text { college) }\end{array}$ & $\begin{array}{l}\text { Video-head at large e-com- } \\
\text { merce company ( } 3 \text { years, in } \\
\text { total } 7.5 \text { years at this company) } \\
+ \text { own company (in film/video, } \\
\text { such as wedding videos); } 3 \\
\text { months at SMA agency }\end{array}$ \\
\hline
\end{tabular}

Table 3. Background of the respondents 
The five interviewees are all working in the same company, which is a small, innovative company with 16 employees, located in one of the Netherlands' major cities. The roles in table 3 are assigned to the employees and they operate in this role in one of the three full service teams that exist within the company. Nearly all the interviewees are about the same age: 28-29, apart from one respondent, who is 52 years old.

\subsection{Respondents and procedure for research question 2}

The second research question is design oriented because we want to make something that supports the SME in their recruitment process. How can these 21st century skills be visualized per team role so that they can be used in recruitment and selection? We designed a workshop together with the strategist of the SMA, who is an expert in design thinking. First, we defined the "why" of a social media architect. The why provides clarity, meaning and direction. It refers to the unique contribution (activities) of an organization and indicates the impact of the work on the environment ("footprint"). It directs the decision making in any organization and is, therefore, important for selecting the most suitable talent for the organization.

The workshop participants consisted of three employees of the company, three researchers and two teachers from a high school who wanted to learn more about new professions to provide better advice to their pupils. High school teachers were involved to address the entire chain. We are currently preparing a publication about the study choice trilemma which explicates that new professions and the changing labor market are not sufficiently taken into account.

In this workshop, we also created a profile of an applicant. The purpose of this was to reveal the characteristics considered important in a whole person. Furthermore, potential candidates must also be attracted to work for this company and industry, so it is vital to know what the team should do to win the hearts of these potential candidates. In groups, we created a persona of an applicant of a specific team role, based on demographic data and several questions such as: What are his/her interests? What does (s)he lose sleep over? What makes him/her happy? What makes him/her proud? And what is (s)he good at and not so good at? We also discussed what might help visualize the 21st century skills and we kept the things we considered important in an applicant per role.

Alongside the workshop, we validated our findings from the interviews in more detail with two SMAs who were not interviewed (step 5 in table 2). They responded to the listed professional activities and the qualifications and competences per role. We recordered and transcribed their responses.

Finally, an educationalist, who is an expert on 21st century learning, checked and assembled the entire set of material. 


\section{Results}

\subsection{Professional activities and "21st century skills" of an SMA}

The results of the first research question were presented at the SEFI conference in Budapest on September 16, 2019 (Sjoer et al. 2019). To understand the meaning of the 21st century skills per role, and to clarify the 21st century skills that should be visualized for recruitment and selection, we will also present these outcomes in this chapter 4.1.

Frequently mentioned 21st century skills of an SMA team The "21st century skills" needed to develop and execute a (media) strategy for a client with a team of SMAs, are shown in Figure 2.

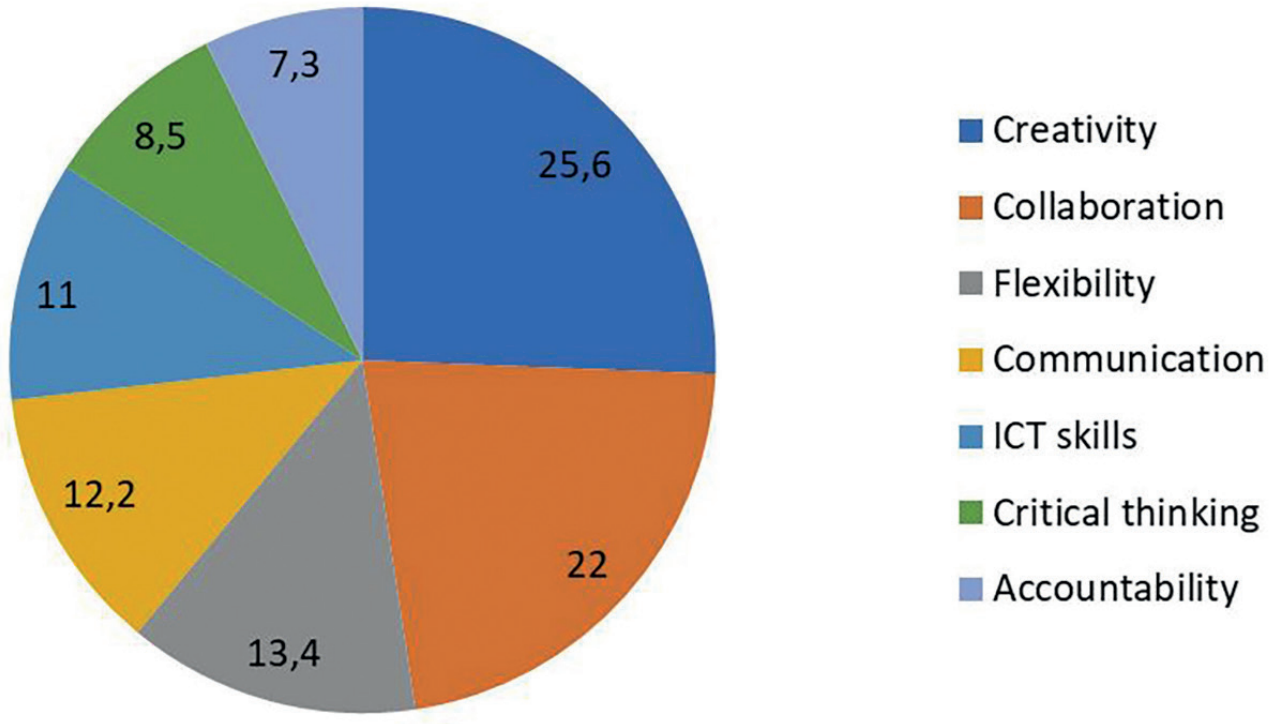

Figure 2. Frequently mentioned 21st century kills of an SMA

The two most frequently mentioned skills are "creativity" and "collaboration". These are two big clusters of skills that seem to be important. The second largest groups are "flexibility", "communication", and "media and technology skills" (in short: ICT skills). The third most important groups of skills are: "critical thinking" and "accountability".

The narrative of these important groups of skills can be defined as follows. In this company, SMAs work as a team. To achieve their common goal they have to be creative (together). They are communicating with each other frequently and thoroughly, as well as with the client. Furthermore, as a person, 
they have to be flexible, media literate and able to apply technology effectively. Finally, as an SMA, you have to manage time and projects successfully and take responsibility for the final results.

To provide an idea of the final results, we give the following example. One assignment is about generating positive media attention during the period that an important tunnel is closed in the city. In order to create understanding among the public, who often used the tunnel, so-called "fixed columns" have been created, generating a constant stream of media attention. When monitoring the impact, it shows that the interaction is good, thus "engagement" continues to rise. Every now and then the team SMAs try their hand at "newsjacking". At Christmas time, the idea was to make a short movie, "our building heroes" about the people who renovate the tunnel, to acquire an attention peak on social media and "to surprise those algorithms again". (After the strategist's story).

Roles and tasks of SMAs differ in the team and with it, the emphasis on particular skills. A strategist seeks for the question behind the clients question and converts it into a communication or media strategy for a specific target group. A designer designs the images and a copywriter writes short, well-chosen texts and scripts. A videographer makes appropriate, surprising videos and a content manager spreads the message that a client wants to communicate. He/she literally posts on Facebook. Finally, a team head (in this case also a videographer), ensures that the team functions well.

\section{Deep dive into the 21st century skills}

The results of the most frequently mentioned 21st century skills: creativity, collaboration, flexibility etc. are not enough to recruit new entrants to the profession. Therefore, we dove deeper into the matter and we made a summary of the professional activities and results per role, the essential knowledge, and the most important 21st century skills that come with it, according to the respondents. Furthermore, we looked at their value proposition, asking questions like: What makes this so cool and interesting for you?

When we take a closer look at what creativity entails, we discover what it means for different roles. For a strategist, it means to use idea generation techniques to gain new ideas (together) and to turn these ideas into a (media) strategy or approach that has an effect on people. Creative thinking and a useful contribution to the client (the result of creativity) are the most important elements. Whereas for the designer, creativity mostly means to be able to demonstrate originality and inventiveness in concrete work, e.g., a logo. A content manager can be confronted with negative reactions after posting a message, and s/he should be creative in re-thinking, which was described as: "to analyse and evaluate own ideas and flip them to the positive side".

To be able to work as an SMA at this company you should be a "team player". All SMAs have to demonstrate their ability to work effectively within a team. Each play a part in a theatre piece, or a music band, so to speak. They 
value each other's contributions, have a willingness to be helpful and to make compromises to accomplish a common goal. "We talk a lot with each other. It's a new industry, it's new work, so there are no paths we can take. [...] Within the team we always consider: are we doing this because we did this last time, or because it works best." (content manager). They also work together with external parties: printers, website builders etc.

Yet, this collaboration requires something different from a copywriter than from a videographer. Although they are both part of a team, the latter can make a video all by him/herself from start to finish, whereas a copywriter's work is often fragmented. S/he should revise many texts of colleagues, or write small texts for different multimedia presentations. This requires flexibility both in time and mindset: "If something needs to be online this afternoon and colleagues want to have it checked, I can say that I don't have time for that, but that won't help anyone. [...] But it also means switching from writing something for a cycle repair shop to writing for a lawyer". A copywriter must be able to adapt to schedules and contexts and has to work in a climate of changing priorities. Adapting to changes also applies to the content manager in relation to the client: "Imagine your content is ready for this week and then the customer calls: "something is happening now and that needs to be communicated quickly". [...] Then all content goes to next week, or to the trash and then you start creating something else.”

Especially creators of tangible products such as texts (copywriter) and images (designer) mentioned that being flexible also means incorporating feedback effectively. "If a colleague thinks something is ugly, you must not relate that too much to yourself". Also with the client, both gave examples of understanding, negotiating and balancing diverse views to reach workable solutions. "If you get the answer [from the client] „that it doesn't feel right”, they actually mean that it is not entirely how they see it. But if that is what their target group is aiming for, if it does what you want to get done, it's best to think about it for a while. [...]. At first I do not agree. I want to talk with the client again.” (copywriter) Another example of understanding and balancing diverse views: "As a designer, you must be able to work for someone else. Sometimes you have to be careful with your own style. We never make things that we don't like, but sometimes you have to make concessions.”

The core-business of an SMA is communication. Almost all SMAs emphasise the ability to listen and to read emotions. Customer empathy is important for the strategist to ask the right questions to get to the real problem; for the designer to get information about the context and intentions; for the copywriter to understand the target group better; and for the content manager to develop a relationship with the client: "they should see you as a colleague". All SMAs use communication for a range of purposes and utilise multimedia and technology. Their core knowledge is about how to judge their effectiveness a priori as well as assessing their impact. The reason that information, media and technology skills did not comprise the most important group of skills 
may be that they take their ability to access and evaluate information, to analyse media and to apply technology effectively for granted.

Regarding the knowledge component, disciplines such as marketing/sales, psychology, communication, and journalism are mentioned. Up-to-date information on legislation (AVG), software expertise (knowledge about packages and programmes, knowledge about the operation of websites, algorithms) and of course role-related knowledge are also mentioned; for example, for the videographer, knowledge of camera equipment and technical expertise about making videos: "what makes a nice shot?”. Nearly all SMAs talk about awareness of new (technological) developments. "What's new in social media?” Upon asking this question, current trends according to the respondents are: more images, ultrashort, personalisation, passion for data.

To have some understanding what drives and motivates SMAs, we asked: What are you most proud of? Four categories emerged from the data:

a. Happy customer: "Who is really satisfied and his expectations have been exceeded."

b. Teamwork: "A final result that everyone has contributed to."

c. Results: "Seeing the result if you pass it or if it is on social media." and "Starting with nothing and creating something very beautiful that tells a story."

d. Effect on the target group: "If it elicits responses that you had hoped for, yes, then I am proud.”

\subsection{Recruitment cards: comprehensive description of the different roles}

In a workshop, attended by all consortium partners, we took the following steps towards a new job design:

1. Why session: with what do we want to create (which) impact (in the future)?

2. Who/what do we need for this? A complex new profession was divided into several roles and combined in full-service teams each with their own focus. What can be split up? What belongs together? What talents do we already have in each team? How do they fit together?

3. What does an ideal applicant look like? We created personal images (personas) of an ideal applicant. This fits in the design-thinking approach: examining the target group. More applicant characteristics could be added to the results of research question 1.

4. How do we make the new job profiles practical for recruitment and selection?

Future-proof recruitment starts with the (re)design of the direction for the future. In the aforementioned workshop, three SMAs, three researchers and two high school teachers defined the most important characteristics of 
an SMA. They conducted a so-called "why" session (step 1) with the following result:

"A social media architect is immersed in the needs of the customer and target group, and, in co-creation, translates this into (digital) content to ensure the conveyed message touches and moves the target group."

The company CEO had already executed step 2. At the workshop, the company owner presented the organizational structure. When he founded the company, he performed all the roles himself. As the company grew, so did the number of roles and the complexity of the tasks, requiring the recruitment of more role specialists. The concept of the three full-service teams with the assigned roles, however, is still subject to change. During the research, the role of designer and videographer have been combined, for example. This role will be defined by the word: "creative."

Since the 21st century skills should be visualized per role to recruit potential candidates, we need a better idea of the target group (step 3). Step 3 of our research revealed what the teams want from a new colleague and the requirements to attract the right person. By developing personas, it became increasingly apparent that the whole person, with their needs, passions, ideals, should be part of every new job profile. We also observed that the partners from outside the company contributed with a broad scope of application. "You need someone from a hotel education background!" stated one of the consortium partners. We jointly created a personal image (persona) of an applicant; an example is shown below.

1 Name:

2 Age:

3 Place of residence:

4 Profile:

5 Background:

6 Interests:

7 Media:

8 What does (s)he lose sleep over?

$9 \quad$ What makes him/her happy?

10 What is (s)he very good at?

11 What is (s)he not so good at?
Samira

25-35

Nearby

Higher-order working and thinking capabilities (but not necessarily academic(!)), catering / hotel training or experience

Job-hopper (someone who knows what's going on)

Broad general knowledge, curious person

Social media minded (digital and offline)

Faltering collaborations

Combining ingredients into a beautiful dish

Rhythm, empathy, communication, planning collaborations, connecting people, bird's-eye view

Not someone who dots the i's. 
From the results of the interviews and the workshop it was possible to list professional activities and the drivers and competences (21st century skills) per role. We validated the results of this role design. Based on these validated results, we designed five recruitment cards, representing the five team roles of a social media architect. This role design, combined in the recruitment cards, fits the stage of the organization. The cards can be used in a manner that best suits the company (not in this paper).

Table 4 provides an example of the role of the content manager and a copy writer (summarized) to show the clearly distinguishable roles with the different requirements for each role.

\begin{tabular}{|c|c|}
\hline Role 1: Content manager & Role 2: Copywriter \\
\hline $\begin{array}{l}\text { Professional activities } \\
\text { Responsible for publishing everything } \\
\text { that is created on the web (on time and } \\
\text { correctly). For this, the content manager } \\
\text { needs approval from the customer. } \\
\text { Monitoring social media channels, and } \\
\text { looking at responses to posts. } \\
\text { [...] } \\
\text { 99\% of the time at the computer. } \\
\text { Content manager and team lead are an im- } \\
\text { portant duo in the team. The content man- } \\
\text { ager is the creative spider in the web, and } \\
\text { the team lead is the practical linchpin. } \\
\text { Knowledge } \\
\text { Knowledge of how a website works: "un- } \\
\text { derstanding that a Facebook algorithm } \\
\text { works in a certain way [...]" } \\
\text { Aware of technological innovations and } \\
\text { developments in social media } \\
\text { Passion: "You must be data-driven, pas- } \\
\text { sionate about anything new." } \\
\text { Collaboration } \\
\text { [Love] collaborating with colleagues on } \\
\text { concrete assignments: "having a brain- } \\
\text { storm with the whole team, because you } \\
\text { get multiple disciplines and expertise to- } \\
\text { gether and you simply get the best ideas." } \\
\text { [...] } \\
\text { Communication } \\
\text { [Very good at] communicating with the } \\
\text { customer and with the customer's target } \\
\text { group [...] }\end{array}$ & $\begin{array}{l}\text { Professional activities } \\
\text { Responsible for all texts } \\
\text { Writing texts, such as scripts, blogs, but also } \\
\text { short texts such as headings, and brand na- } \\
\text { mes. } \\
\text { Editing and correcting text written by others } \\
\text { [...] } \\
\text { Work is very fragmented. } \\
\text { Trends: ultra-short! Text into images } \\
\text { Knowledge } \\
\text { Knowledge of spelling and grammar [...] } \\
\text { Passion: Delivering high-quality, original } \\
\text { texts, and overcoming any of the customer's } \\
\text { initial doubts about the effect on the target } \\
\text { group. "We are all happy with the outcome: } \\
\text { This is how it ought to be!” } \\
\text { Collaboration: } \\
\text { [Likes] creating something together: "We } \\
\text { worked very hard on a tender last week. All } \\
\text { five of us were literally working on the same } \\
\text { document. I looked at the texts, another at } \\
\text { the design, and another colleague dealt with } \\
\text { the budget. It was very satisfying." } \\
\text { Communication: } \\
\text { Takes communication (including spelling) } \\
\text { seriously [...] } \\
\text { Being able to make complex matters concre- } \\
\text { te and easy to explain: "You have to be able } \\
\text { to state everything in one or two sentences. } \\
\text { Or at least to persuade someone to read on.” } \\
\text { [...] } \\
\text { The ability to listen, to read emotions and to } \\
\text { understand the customer, and most impor- } \\
\text { tantly, the customer's target group. }\end{array}$ \\
\hline
\end{tabular}




\section{Creativity}

creating just a little bit [...]

\section{Critical Thinking}

The content manager analyzes the (patterns of) impact of social media posts by providing data. The strategist takes the lead and draws conclusions based on the provided data. [...]

\section{IT skills}

[Good at] being able to apply IT: the con-tent manager is the one who posts everything

\section{Flexibility}

Adapts to schedules and contexts [...]

Organizational and planning skills

Remains calm under pressure and thinks on their feet: "make sure that everyone's on board."

\section{Accountability}

A content manager must feel a special sense of responsibility towards a project. [...]

\section{Creativity}

Demonstrates originality and inventiveness: "If I have to write a script for a motion graphic or have to come with a new name for a brand, I sometimes sit on the bike with a scrap of paper in front of me."

Critical thinking

When dealing with colleagues and customers, you must remain critical and sometimes dare to stay firm.

IT skills

Just basic skills

Flexibility

Incorporating feedback effectively, from colleagues and customers

Understanding, negotiating, and balancing diverse views to reach workable solutions Flexible with time: can adapt to schedules Flexible mindset: "Switching from writing something for a bicycle shop to a piece for a lawyer."

Organizational and planning skills Being able to organize your time well: "A creative may be working on one or two design jobs, but I sometimes work on twenty different things [...] it is very fragmented.”

Table 4: Two examples of recruitment cards

\section{Conclusion}

In this paper, we researched the pre-recruitment phases of a new hiring for a small company of social media architects. Social media architect (SMA) is a new profession. It combines several roles: strategist, designer, copywriter, videographer, content manager, and team lead. Small social media architect enterprises are growing rapidly and they need more detailed information on the qualifications (21st century skills) of new hires since they cannot fall back on relevant study programs or work experience. In line with the working methods in the creative sector, we explored a design-based (pre)recruitment approach. In this approach, in co-creation we defined the role qualifications and described a job profile connected to the organization's needs. An SMA, two universities of applied sciences and a high school jointly addressed the challenges of a changing labor market.

First, the university researchers thoroughly investigated this newly created job by conducting in-depth interviews with the SMAs. The 21st century skills that a team of social media architects need most are from the learning and 
innovation skills cluster of the P21 framework: creativity and collaboration. From the cluster of life and career skills: "flexibility and adaptability" and "productivity and accountability" stand out. An SMA should be able to adapt to change, and must work effectively in a climate of ambiguity. Surprisingly, the information, media and technology skills cluster was mentioned less often, but it was named in conjunction with the required knowledge of an SMA. Moreover, we think that SMAs take the IT-related skills for granted. If a social media architect is known for anything, they are known for the crossover between (social media) communication and (multimedia) technology. An interest in social media, customer empathy and creativity go well with creating media products and using digital technologies effectively.

However, knowing what the frequently mentioned 21st century skills are does not automatically lead to new job profiles. We need to look deeper into the different roles, the professional activities and results, and the desired qualities. In this way, the 21st century skills framework can be used in a meaningful way. For instance, take "creativity," if we compare all the creativity quotes for the roles an SMA can adopt, a strategist should be good at organizing "creative thinking" (together), a designer and copywriter should provide "creative work" (with others) - meaning demonstrating originality and inventiveness in work such as logos, appealing text lines - and a content manager should be good at "implementing creative innovations". Furthermore, in the interviews we also asked about the passion, drivers and emotions that go with the job. "What makes you proud?" These motivations and driving forces are important and reveal the role's professional identity.

The second research question was a design-oriented question aimed at exploring a new approach and creating a practical product that can be used for recruitment and selection. In most companies, job descriptions are standard or sample job specifications are easily obtained for most existing jobs. That was not the case in this company, however, as social media architect is a new and developing job in a fast-changing market. The recruitment process is unstructured and intuitive and mainly carried out by the company owner. The challenge was to remain flexible, while providing some structure.

In line with the way SMAs work in the creative sector and the development stage of the company, the job roles and corresponding profiles were built bottom-up and in co-creation in this study. SMAs, university researchers and high school teachers shaped the roles together. First, they delved deeply into the rapidly changing context of an SMA, the companies development strategy (working in full-service teams), the contribution of every team member and what this requires of a person (see research question 1). Not only did they consider the "skills" and required knowledge, but also the emotions, values, and motivations. Second, in this rapidly changing world, you cannot rely on standard HR methods and procedures. Instead, we used marketing techniques to indicate the future direction, create the elements of personas and design job roles. This approach provided clearly distinguishable, flexible roles with 
corresponding qualifications. After which, we processed all the collected data into five customizable recruitment cards.

The strength of this approach is that we start with collecting rich data about roles instead of jobs or functions. An SMA team comprises multiple roles and it is possible to combine (part of) these roles, depending on the talents of the employees and/or applicants. Breaking down the complex SMA function into roles and then dividing (aspects of) the roles, based on what a person can do and what the organization needs, offers several advantages. This method enables an organization to remain flexible. Furthermore, the company can offer people space to develop themselves.

Further evaluation research is needed into how the recruitment cards can be implemented successfully. We need to know more about the effectiveness and efficiency of the cards to improve them and scale up the approach. From this study, it became clear that for new job profiles fitting the needs of growing SMEs in the fast changing labor market, it is helpful to:

- Take a design-based approach to developing job roles, together with other parties (outside the company);

- Delve deeper when considering appropriate "skills," otherwise frameworks such as 21st century skills will be meaningless;

- Use methods from other disciplines that fit the organization's culture, in our case elements of design sprints for HR purposes;

- Include the "knowledge" required alongside "skills";

- Intertwine the "skills" (that are often not "skills") with the personal narrative of the applicant to reveal the needs, beliefs, emotions, passion, etcetera ("role identity");

- Have the courage to go beyond traditional job descriptions listing job responsibilities and required education and credentials;

- Look at the rapidly changing context and the value this company (staff) wants to add together.

The recruitment cards we made are not static products. The company could add new cards, and the content is subject to change depending on the direction of the organization, the possibilities for growth and the people who work there. In this way, we can incorporate flexibility, which is necessary for a new profession and for companies with changing job positions to enable them to stay future-proof and provide opportunities for lifelong development.

\section{References}

Battelle for Kids. "Frameworks \& Resources." and "Framework for 21st century learning. Definitions”, Accessed April 24, 2019 (wwwP21.org) and July 28, 2020. https://www.battelleforkids.org/networks/p21/frameworks-resources. 
Biemans, Petra, Ellen Sjoer, Rien Brouwer and Karin Potting. Werk verandert: 21st century skills in de praktijk. Den Haag: Hogeschool Inholland; De Haagse Hogeschool, 2017. [in Dutch only].

Dachs, Bernhard. The impact of new technologies on the labour market and the social economy. Brussels: STOA, 2018.

DenkWerk. Labor in transition - How man and technology can work together. Summary, 2019.

Frey, Carl and Michael Osborne. The Future of Employment: How Susceptible Are Jobs to Computerisation? Oxford: Martin. 2013. https://doi.org/114. 10.1016/j.techfore.2016.08.019.

Frey, Carl Benedikt and Michael A. Osborne. „The future of employment: How susceptible are jobs to computerisation?," In: Technological Forecasting and Social Change, Elsevier, vol. 114, no. C, (2017): 254-280. https://doi.org/10.1016/j.techfore.2016.08.019

Hilt, Line T., Hanne Riese and Gunn Elisabeth Søreide. "Narrow identity resources for future students: the 21st century skills movement encounters the Norwegian education policy context.” Journal of Curriculum Studies 51, no. 3 (2019): 384-402, https://doi.org/ 10.1080/00220272.2018.1502356.

Miller, Ben and Robert D. Atkinson. “Are Robots Taking Our Jobs, or Making Them?” The Information Technology \& Innovation Foundation. September 2013.

Sawchuk, Stephen. "Motives of 21st-Century-Skills Group Questioned.” Education Week, 29, no.14 (December 2009): 18-21.

Sjoer, Ellen, Jeany Beelen-Slijper, Petra Biemans, and Frans Jacobs. "Cross-overs in technology-related jobs. 21st century skills of a social media architect.” In: Varietas delectat... Complexity is the new normality. Proceedings of The 47th SEFI Annual Conference, Budapest, 16-19 September 2019.

Voogt Joke and Natalie Pareja Roblin. "A comparative analysis of international frameworks for 21st century competences: Implications for national curriculum policies”. Journal of Curriculum Studies 44, no. 3 (2012): 299-321, https://doi.org/10.1080/00220272.2012.668938 World Economic Forum. The Future of Jobs. Employment, Skills and Workforce Strategy for the Fourth Industrial Revolution. Global Challenge Insight Report, January 2016. 